\title{
EVALUATION OF HEMATOLOGICAL PARAMETERS AS A POSSIBLE MARKER FOR HEAD-AND-NECK CANCER AND PRECANCEROUS CONDITIONS
}

\author{
Abhinandan Bhattacharjee ${ }^{1}$, Florence Ratna Borah², Giri Sarbani ${ }^{3}$, Bapan Devnath ${ }^{4}$, S. Uddin 5 \\ 1Phd. Scholar, Department of Life Science and Bioinformatics, Assam University, Silchar. \\ 2Post Graduate Trainee, Department of ENT, Silchar Medical College, Assam. \\ ${ }^{3}$ Professor, Department of Life Science and Bioinformatics, Assam University, Silchar. \\ ${ }^{4}$ Post Graduate Trainee, Department of ENT, Silchar Medical College, Assam. \\ 5 Professor, Department of ENT, Silchar Medical College, Assam.
}

ABSTRACT

\section{BACKGROUND}

Head neck cancer (HNCA) is a major health problem, accounting for 30-40\% cancers at all sites with the incidence in North-East India, where this study has been conducted is highest in the country (54.48\%). As various substances alter quantitatively in the serum during tumor development, we intended to explore the changes in the haematological profile in cases of head neck squamous cell carcinoma and epithelial precursor lesions. Moreover, such study will be the first on HNCA patients in this North East region of India.

\section{AIMS}

To assess the variations of haematological and biochemical parameters in HNSCC and Epithelial precursor lesions of the head and neck.

\section{METHODS AND MATERIAL}

Blood samples from the cases were collected to quantify $\mathrm{Hb} \%$, hematocrit, RBC count, MCV, MCH, MCHC, TLC, RDW-CV, blood urea, creatinine and glucose levels. Using ANOVA test, the difference in various groups were compared and the significance obtained.

\section{RESULTS}

Our study showed extremely significant difference in $\mathrm{Hb} \%$ level in both the HNSCC and EPL group from the control population. There was no significant correlation between WBC count and the development of SCC or EPL. MCHC and MCV was found to be high in majority of cases and the difference of MCHC among the three groups was found to be extremely significant. We found elevated RDW-SD levels in majority of cases in both groups while mean ESR level was very high in EPL group only. However, blood biochemistry parameters did not reveal any significant results.

\section{CONCLUSIONS}

The present study shows that among different hematological parameters, Hb\%, MCHC, MCV, RDW, SD and ESR are significantly altered in HNCA and premalignant states. Present study also confirms that there is no significant correlation between WBC count and HNCA. The grossly raised MCHC, RDW-SD and ESR values in both cancerous and precancerous lesion of HNCA point out that these parameters should be considered collectively during evaluation of HNCA patients. The variations in these parameters may be useful in the prediction of malignant transformation, prognosis or in treatment progress.

\section{KEYWORDS}

Head Neck Squamous Cell Carcinoma, Premalignant Lesions, Red Blood Cell Indices, Anaemia, White Blood Cell, Hematological Profile.

HOW TO CITE THIS ARTICLE: Abhinandan Bhattacharjee, Florence Ratna Borah, Giri Sarbani, Bapan Devnath, S Uddin. "Evaluation of Hematological Parameters as a Possible Marker for Head-and-Neck Cancer and Precancerous Conditions." Journal of Evolution of Medical and Dental Sciences 2015; Vol. 4, Issue 95, November 26;

Page: 16111-16116, DOI: 10.14260/jemds/2015/2357.

\section{INTRODUCTION}

HNCA is a major health problem accounting for $30-40 \%$ cancers at all sites while the incidence in North-East India,

Financial or Other, Competing Interest: None.

Submission 30-10-2015, Peer Review 31-10-2015,

Acceptance 16-11-2015, Published 26-11-2015.

Corresponding Author:

Dr. Abhinandan Bhattacharjee,

H.No: 23/23, Green Park,

Silchar-788015.

Assam.

E-mail: dr_abhinandan1@rediffmail.com

DOI:10.14260/jemds/2015/2357. where this study is being conducted is higher than the rest of the country (54.48\%). ${ }^{1}$ Biomarkers are valuable adjuncts in cancer treatment and as such many studies on blood biochemistry and hematology to explore the etiology of cancers and to establish tumor markers has been undertaken. As various substances alter quantitatively in the serum during tumor development, we intended to explore the changes in the haematological profile in HNSCC and Epithelial Precursor Lesions (EPL) cases. Moreover, such study will be the first on HNCA patients in this North East region of India. 


\section{AIMS AND OBJECTIVES}

1. To assess the variations of red blood cell indices in HNSCC and epithelial precursor lesions of the head and neck.

2. To assess the relationship between circulating white blood cell parameters with HNSCC and premalignant lesions.

\section{MATERIALS AND METHODS}

This study was carried out on 61 patients at Silchar Medical College Hospital under Department of Life Sciences, Assam University beginning from 2012 till 2014. The patients, age ranging from 20-70 years were clinically diagnosed and HNCA confirmed after histopathological examination. In our study, HNCA cases represented squamous cell carcinoma of sites and subsites in upper aerodigestive tract as per ICD10 system. Patients with muscle dystrophy, diabetes, hypertension, renal, cardiac or hepatic disease, periodontitis, previous history of malignancy or cancer treatment were excluded from the study. The demographic information regarding gender, age and personal tobacco history were prospectively collected along with clinical, biochemical and pathological data. Thirty one diagnosed cases of Squamous Cell Carcinoma of Head and Neck (HNSCC) comprised the HNSCC group. The second group comprised of thirty cases of clinically diagnosed epithelial precursor lesions (vizleukoplakia, erythroplakia, keratosis and oral submucous fibrosis). After thorough evaluation, thirty age and sex matched subjects were selected for the control group, the mean age was $61.5 \pm 8.4$ years.

These subjects had no health problems and never exposed to any cancer related treatment. The Haemoglobin (Hb), Erythrocyte Count (RBC), Packed Cell Volume (PCV), Mean Corpuscular Volume (MCV), Mean Corpuscular Haemoglobin (MCH), Mean Corpuscular Haemoglobin Concentration (MCHC), RDW-CV, blood urea, creatinine and glucose levels were measured. This study was carried out after obtaining approval of the Institutional Ethical Committee of Silchar Medical College and Hospital. Each patient signed an informed consent form before participating in the study.

Sample collection and analysis: Blood samples were collected from arm vein of all the 91 subjects. Control group blood samples were also taken at the same day and same method as of the other group. Blood tests for $\mathrm{Hb} \%$, hematocrit, RBC count, MCV, MCH, MCHC and Total Lymphocyte Count (TLC) were done in Sysmex 500i Autoanalyser machine. RDW-CV (Red cell distribution width as coefficient of variation), expressed in $\%$ is calculated as: RDW-CV(\%)=1 SD of RBC volume/MCVx $100 \% .^{2}$ Statistical analysis of data were done using the GraphPad Instat for Windows software, Version 3.05 (GraphPad Inc., CA, USA). Analysis of variance (ANOVA) and Duncan test were used to compare differences between groups and the significance level of $\mathrm{p}<.05$ was considered. The data were displayed as means \pm standard deviation (SD).

\section{OBSERVATIONS AND RESULTS}

Demographic Pattern: Out of total 61 cases of head and neck lesion included in the study, 31 cases (Group A) were Squamous Cell Carcinoma (SCC) and 30 cases (Group B) were of Epithelial Precursor Lesion (EPL). The control group (Group C) consisted of age and sex matched disease-free population of 30 individuals. The mean age in Group A, Group
B and control group were 55.7 years, 47.1 years and 61.5 years respectively. Male:female ratio for the three groups were 26:5, 18:2 and 21:9 respectively. Orophayngeal cancer was the commonest site (48\%) in group A whereas oral cavity (70\%) was commonest for group B. (Table 1 )

\section{Head and Neck Subsites}

In the EPL group, the highest number cases were found in oral cavity $(70 \%)$ and SCC was commonest in oropharynx (48.4\%). Fibrous hyperplasia was the commonest epithelial precursor lesion seen followed by moderate dysplasia. (Table 2).

\section{Hematological Tests WBC Count}

Out of 31 patients with HNSC, 5 had an elevated WBC count of 6.8-15.0 cells $/ \mu \mathrm{L}$. No significant correlation could be found between WBC count and the development of SCC or EPL. Neutrophil count in EPL group was found to be higher than other group but this was not significant. (Table 3).

\section{Red Blood Cell Count}

The mean RBC count in SCC group and EPL group was 4.5 \pm .9 and $4.6 \pm .52$ respectively. The difference between these groups and the control cases was statistically not significant. (Table 3).

\section{Hemoglobin}

Our study revealed extremely significant difference in $\mathrm{Hb} \%$ level in both the SCC $(11.1 \pm 1.8)$ and EPL group (12.4 \pm 1.8$)$ from the control population (Fig 1).

\section{Red Blood Cell Indices}

The mean MCHC level was $29.2 \pm 3.6$ in SCC group as compared to $33.86 \pm 2$ in control group (Fig 1). The difference in values were not statistically significant.

\section{Platelet Count}

The mean platelet count for SCC patients were found to be $161.5 \pm 42.6$, which is substantially less than the mean level in control group. This variation was highly statistically significant. Similarly, very significant difference was also noted between EPL and the SCC group. (Table 3).

\section{Erythrocyte Sedimentation Rate}

Very high mean ESR was noted in the EPL group (30.9 \pm 14.8$)$, whereas in SCC group the mean level was marginally high. When compared with the control group, the difference in levels were found to be statistically very significant. (Table 3).

\section{Blood Glucose Level}

We also assessed the blood glucose level and found mildly raised values in the EPL group, $(145.9 \pm 20 \mathrm{mg} / \mathrm{dl})$. However, blood glucose levels were statistically not significant. (Table 4)

\section{Blood Urea and Creatinine}

The mean blood urea level in both the study groups were within normal range. Similarly, blood creatinine level also did not reveal any abnormality. Both these parameters when compared with the control group was not found to be statistically significant. (Table 4) 


\section{DISCUSSION}

In India, HNCA is a major health problem, accounting for 30$40 \%$ cancers at all sites with its incidence in North-Eastern India at $54.48 \% .^{1}$ Potentially malignant lesions of oral cavity are relatively common occurring in about $2.5 \%$ of the population with a malignant transformation rate of 0.6 to $20 \%$ as reported in various studies and locations. ${ }^{3}$ Identification of molecular markers in blood would predict the development of cancer in its earliest stage or in precancerous stage. Literature scan reveals very few studies on $\mathrm{RBC}$ indices and role of WBC count in the diagnosis of malignancies of the head and neck. As till date no such study has been undertaken in this highly prevalent region of NorthEast India, our study examined the variations of these parameters in HNSCC and EPL patients and their role as biomarkers. In our study, orophayngeal cancer was the commonest site (48\%) in HNSCC group whereas oral cavity (70\%) was commonest for EPL group. In western world, with an incidence of $5 \%$, the outcome of oral squamous cell carcinomas (OSCC) has hardly shown any improvement. ${ }^{4}$ The annual worldwide incidence of OSCC is over 300,000 cases, accounting for $2-4 \%$ of all new cancers. ${ }^{4}$ and its $5 \%$ for oropharyngeal cancers in the western world. ${ }^{5}$ In India, where the habits of chewing tobacco with betel nut, reverse smoking and heavy alcohol usage are common, its incidence is even higher. ${ }^{1}$

\section{White Blood Cell Count (WBC)}

WBC is highly variable because it is responsive to diverse acute and chronic stimuli. It is elevated by infection, stress and chronic irritative exposures like smoking. ${ }^{6}$ But due to its nonspecificity, WBC count can predict risk for multiple diseases including cancer, coronary heart disease. ${ }^{7}$ or stroke. ${ }^{8}$ Studies have reported that the WBC count is significantly associated with risk of cancer death. ${ }^{9,10}$ and total cancer mortality. ${ }^{11,12}$ However, studies on the relationship of WBC count and HNSCC are rare. Tsai et al., in his study on oral cavity cancer, showed that the peripheral total white blood cell (WBC) count, monocyte, and neutrophil counts and neutrophil lymphocyte ratio increased with the stage T4 and poor tumor differentiation. ${ }^{13}$ Check et al., using FicollHypaque gradient analysed the correlation of (WBC) count and the percentage of lymphoid cells in HNCA. ${ }^{14}$ Kuss L et al., found altered lymphocyte homeostasis in HNSCC cases which persisted for months or years after curative therapies. ${ }^{15}$ Kruse et al., reported that the only correlation that could be found was for T status and WBC, and that seems to have no clinical relevance and also concluded that WBC count is not a prognostic factor for recurrence of metastases. ${ }^{16}$ To the authors' knowledge, our study is the first to look into the association of WBC count and HNCA. Present study revealed no significant correlation between WBC count and the development of SCC or EPL. On the other hand, significant relation between CRP and IL with tumour stage., ${ }^{17,18}$ overall outcome., ${ }^{19}$ and radiotherapy induced acute mucositis. ${ }^{20}$ were noted. This may indicate that precancerous lesions are associated with inflammation, like erosive lichen which warrants investigation on the relation between inflammatory markers like CRP and WBC counts. ${ }^{21}$ Infact, elevated neutrophil count has been observed in our study though not statistically significant. These evidences point that in a mileu of inflammatory cells, growth factors, and activated stroma genetic damage leading to cellular proliferation is possible. ${ }^{21}$ The WBC analysis in our study would have been more reliable if multiple measurements were taken instead of one as WBC count shows day to day variability and if data on confounding factors like medicine intake were taken into consideration.

\section{Erythrocyte Count}

Anaemia is known to influence prognosis of HNCA patients, but how anaemia and epithelial precursor lesions influences each other is not clear. Most studies dealt with the effect of anaemia on patients receiving radiotherapy. ${ }^{22,23}$ and surgical treatment., ${ }^{24}$ but the present study investigates the relation of erythrocyte and iron indices to HNCA and EPL patients. Our study revealed extremely significant difference in $\mathrm{Hb} \%$ level in both the HNSCC and EPL group from the control population. We found anaemia more in SCC than in EPL groups in terms of $\mathrm{Hb} \%$ (87.1\% vs $73.3 \%)$, RBC $(51.6 \%$ vs $46.7 \%)$ and HCT $(74.2 \%$ vs $50 \%)$. Bhattathiri VN also reported that most of the patients were anaemic in terms of Hb (63\%), RBC (43\%) and HCT (48.4\%). ${ }^{25}$ This shows that anaemia is associated more with SCC than normal population (33.3\%, 23.3\% and 53.3\% respectively). Claudia Cordella reported $18.5 \%$ cases as mild anemia and $10.1 \%$ in the severe anemia group and showed association of low $\mathrm{Hb}$ levels with the lymph node metastasis $(\mathrm{p}=0.005)$, but not the initial $\mathrm{T}$ status $(p=0.183){ }^{24}$ Other studies suggested that prechemoradiation $\mathrm{Hb}$ level to be an important determinant of outcome in carcinoma esophagus. ${ }^{26}$ Studies by Hefler, Qiu and Cordella $\mathrm{C}$ have also shown that hemoglobin concentration of below $11 \mathrm{~g} / \mathrm{dl}$ contributes to poor prognosis. The fall in $\mathrm{Hb}$ level in both our study groups may be due to nutritional deficiency, impaired oral intake and socio-economic condition. Anemia could also be a marker for other risk factors, such as p53 mutation, loss of heterozygosity (LOH), HPV, etc. ${ }^{24,27,28}$

\section{Thrombocyte Count}

A lower platelet count was seen in $25.8 \%$ and $10 \%$ cases in SCC and EPL group respectively but there was no case of thrombocytopenia.Lu CC reported that thrombocytosis was an independent predictor of shorter survival.,29 but Kargus et al., did not confirm it as a marker for poor tumor prognosis. ${ }^{30}$

\section{Red Cell Distribution Width (RDW)}

We also assessed RDW that measures anisocytosis, described as variability of red blood cell volume or size. RDW can be reported statistically as coefficient of variation (RDW-CV) and/or standard deviation (RDW-SD)(SD). We found elevated RDW SD levels in majority of cases in both SCC (86.7\%) and EPL $(80 \%)$ group and only in $33.3 \%$ of control cases. This indicates that one of the major cause of anaemia is nutritional deficiencies such as iron, folate, or vitamin B12 deficiency as RDW becomes elevated earlier than other red blood cell parameters. ${ }^{31,32}$

\section{Red Cell Indices}

The MCH parameter ranged from normal or high in more than half of the cases of SCC and EPL group (65\% vs $50 \%$ respectively). A high majority of cases had normal MCV in both SCC and EPL group (79\% vs $84 \%$ respectively). The MCHC level was less than normal in $93.6 \%$ cases of SCC as compared to $70.7 \%$ reported by Bhattathiri et al. ${ }^{25}$ The difference of MCHC in the three groups was found to be extremely significant suggesting iron deficiency as a prominent cause of anaemia in our study population. However, this fact is not unexpected as HNSCC cases are 
prone to poor nutrition because of difficulties in food intake, swallowing and absorption from tumor-related mechanisms in addition to tumor-induced metabolic abnormalities. ${ }^{33}$

\section{Erythrocyte Sedimentation Rate}

ESR is the length in mm of clear plasma in a vertical tube after erythrocytes have settle in anticoagulated whole blood, under gravity, in one hour. It indicates severity of illness. As ESR depends on rouleaux formation, red blood cell number, size and shape, electrostatic charges and plasma viscosity. ${ }^{34}$ In normal states, sialic acid residues on red blood cells negates rouleaux formation, but during inflammation, fibrinogen, an acute-phase protein, neutralises sialic acid residues thus contributing to $60-70 \%$ of the increase in ESR. 35 Other proteins which play similar role are beta-globulins, alphaglobulins, gamma-globulins and albumin. The very high mean ESR seen in premalignant states may be due to the increase in acute phase proteins mentioned above in addition to anaemia, polycythaemia and advancing age of the patients.

\section{Blood Biochemistry}

The study confirms that HNCA per se does not have any direct effect on the blood levels of urea, creatinine and glucose. Although, kidney involvement secondary to chemotherapy and or radiation may lead to derangements in renal function.

\section{REFERENCES}

1. A Bhattacharjee, A Chakraborty, P Purkaystha. Prevalence of Head and Neck Cancer in the North-East India-An institutional study. Indian Journal of Otolaryngology and head and neck surgery. Indian Journal of Otolaryngology and Head and Neck Surgery. Vol 58:1;15-19. 2006.

2. Briggs C, Bain BJ. Basic Haematological Techniques. In: Bain BJ, et al. eds. Dacie and Lewis Practical Haematology, 11 $11^{\text {thed. }}$ Philadelphia: Churchill Livingstone/Elsevier; 2012:chap 3.

3. McCullough MJ, Prasad G, Farah CS. Oral mucosal malignancy and potentially malignant lesions: an update on the epidemiology, risk factors, diagnosis and management, Aust Dent J., 2010 Jun;55 Suppl 1:61-65.

4. Grimminger CM, Danenberg PV. Update of prognostic and predictive biomarkers in oropharyngeal squamous cell carcinoma: a review. Eur Arch Otorhinolaryngol. 2011 Jan;268(1):5-16.

5. Reznick AZ, Hershkovich O, Nagler RM. Saliva-a pivotal player in the pathogenesis of oropharyngeal cancer. $\mathrm{Br} J$ Cancer 2004;91:111-8.

6. Jee SH, Park JY, Kim HS, Lee TY, Samet JM. White blood cell count and risk for all-cause, cardiovascular, and cancer mortality in a cohort of Koreans. Am J Epidemiol 2005;162(11):1062-9. doi: 10.1093/aje/kwi326. [PubMed] [Cross Ref].

7. Madjid M, Awan I, Willerson JT, Casscells SW. Leukocyte count and coronary heart disease: implications for risk assessment. J Am Coll Cardiol. 2004;44(10):1945-56.

8. Lee CD, Folsom AR, Nieto FJ, Chambless LE, Shahar E, Wolfe DA. White blood cell count and incidence of coronary heart disease and ischemic stroke and mortality from cardiovascular disease in AfricanAmerican and white men and women: atherosclerosis risk in communities study. Am J Epidemiol. 2001 Oct;15:pp. 758-64.
Raised blood sugar levels as a result of stress or any preexisting diabetes may be encountered but elevated blood sugar levels cannot be considered as an indicator for malignancy or its transformation.

\section{CONCLUSION}

The present study shows that among different hematological parameters $\mathrm{Hb} \%$, MCHC, MCV, RDW SD and ESR are significantly altered in HNCA and premalignant states. Present study also confirms that there is no significant correlation between WBC count and the development of SCC or EPL. Although RBC count is not altered, nutritional anaemia is found to be most prominent finding in premalignant as well as cancer patients. Considering the grossly raised MCHC, RDW SD and ESR values along with low $\mathrm{Hb} \%$, in cancerous and precancerous lesion of HNCA. We suggest that these parameters should be considered collectively during evaluation of HNCA patients. The variations in these parameters may be useful in the prediction of malignant transformation, prognosis or treatment progress. Further study on a larger population and its response to anticancer therapy needs to be pursued before establishing these parameters as HNCA biomarkers.

9. Grimm RH Jr, Neaton JD, Ludwig W. Prognostic importance of the white blood cell count for coronary, cancer, and all-cause mortality. JAMA. 1985;254(14):1932-7.doi: 10.1001/jama.254.14.1932.[PubMed] [Cross Ref].

10. Hoffman M, Blum A, Baruch R, Kaplan E, Benjamin M. Leukocytes and coronary hear disease. Atherosclerosis 2004;172(1):1-6. doi: 10.1016/S0021-9150(03)001643. [PubMed] [Cross Ref].

11. Erlinger TP, Muntner P, Helzlsouer KJ. WBC count and the risk of cancer mortality in a national sample of U.S. adults: results from the Second National Health and Nutrition Examination Survey mortality study. Cancer Epidemiol Biomarkers Prev 2004;13(6):1052-6. [PubMed].

12. Shankar A, Mitchell P, Rochtchina E, Tan J, Wang JJ. Association between circulating white blood cell count and long-term incidence of age-related macular degeneration: the Blue Mountains Eye Study. Am J Epidemiol. 2007;165(4):375-82.

13. Tsai YD, Wang CP, Chen CY, Lin LW, Hwang TZ, Lu LF, Hsu HF, Chung FM, Lee YJ, Houng JY. Pretreatment circulating monocyte count associated with poor prognosis in patients with oral cavity cancer. Head Neck. 2014 Jul;36(7):947-53.

14. Irene J. Check, Robert L. Hunter, Ben Lounsbury, Karen Rosenberg, Gregory Matz. Prediction of survival in head and neck cancer based on leukocyte sedimentation in ficoll-hypaque gradients. The Laryngoscope 1980;90(8):1281-90.

15. Kuss I, Hathaway B, Ferris RL, Gooding W, Whiteside TL. Imbalance in absolute counts of T lymphocyte subsets in patients with head and neck cancer and its relation to disease. Adv Otorhinolaryngol. 2005;62:161-72.

16. Astrid L Kruse, Heinz $\mathrm{T}$ Luebbers, Klaus W Grätz. Evaluation of white blood cell count as a possible prognostic marker for oral cancer Head Neck Oncol 2011;3:13. 
17. Gallo O, Gori AM, Attanasio M, Martini F, Giusti B, Brunelli T, Gallina E. Interleukin-6 and acute-phase proteins in head and neck cancer. Eur Arch Otorhinolaryngol. 1995;252(3):159-62.

doi: 10.1007/BF00178104. [PubMed] [Cross Ref].

18. Jablonska E, Piotrowski L, Grabowska Z. Serum Levels of IL-1b, IL-6, TNF-a, sTNF-RI and CRP in Patients with Oral Cavity Cancer. Pathol Oncol Res. 1997;3(2):126129. doi: 10.1007/BF02907807.[PubMed] [Cross Ref].

19. Khandavilli SD, Ceallaigh PO, Lloyd CJ, Whitaker R. Serum C-reactive protein as a prognostic indicator in patients with oral squamous cell carcinoma. Oral Oncol. 2009;45(10):912-4.

20. Ki Y, Kim W, Nam J, Kim D, Park D, Kim D. C-reactive protein levels and radiation-induced mucositis in patients with head-and-neck cancer. Int J Radiat Oncol Biol Phys. 2009;75(2):393-8. doi:

21. Coussens LM, Werb Z. Inflammation and cancer. Nature. 2002;420(6917):860-7. doi: 10.1038/nature01322. [PMC free article] [PubMed] [Cross Ref]

22. Becker A, Stadler P, Lavey RS, Hansgen G, Kuhnt T, Lautenschlager C, Feldmann HJ, Molls M, Dunst J. Severe anemia is associated with poor tumor oxygenation in head and neck squamous cell carcinomas.Int J Radiat Oncol Biol Phys. 2000;46:459-466. doi: 10.1016/S0360-3016(99)00384-3. [PubMed][Cross Ref]

23. Brizel DM, Dodge RK, Clough RW, Dewhirst MW. Oxygenation of head and neck cancer: changes during radiotherapy and impact on treatment outcome. Radiother Oncol. 1999;53:113-117

24. Claudia Cordella, Heinz-Theo Luebbers, Valentina Rivelli, Klaus W Grätz, Astrid L Kruse. An evaluation of the preoperative hemoglobin level as a prognostic factor for oral squamous cell carcinoma. Head Neck Oncol. 2011;3:35.

25. Bhattathiri VN. Relation of erythrocyte and iron indices to oral cancer growth. Radiother Oncol. 2001 May;59(2):221-6.

\begin{tabular}{|c|c|c|c|}
\hline & $\begin{array}{c}\text { SCC } \\
(n=31)\end{array}$ & $\begin{array}{c}\text { EPL } \\
(n=30)\end{array}$ & $\begin{array}{c}\text { Control } \\
(n=30)\end{array}$ \\
\hline Age & $\begin{array}{l}55.7 \\
11.4\end{array}$ & 47.114 .2 & 61.58 .4 \\
\hline $\mathrm{M}: \mathrm{F}$ & $26: 5$ & $18: 2$ & $21: 9$ \\
\hline \multicolumn{4}{|c|}{ Site of HNCA } \\
\hline Oral Cavity & 4 & 21 & $\mathrm{X}$ \\
\hline Oropharynx & 15 & 1 & $\mathrm{X}$ \\
\hline Larynx & 5 & 6 & $\mathrm{X}$ \\
\hline Hypopharynx & 7 & 2 & $\mathrm{X}$ \\
\hline
\end{tabular}

26. Hefler L, Mayerhofer K, Leibman B, Obermair A, Reinthaller A, Kainz C, Tempfer C. Tumor anemia and thrombocytosis in patients with vulvar cancer. Tumour Biol. 2000;21:309-314. doi: 10.1159/000030136.

27. Qiu MZ, Yuan ZY, Luo HY, Ruan DY, Wang ZQ Wang FH, Li $\mathrm{YH}, \mathrm{Xu}$ RH. Impact of pretreatment hematologic profile on survival of colorectal cancer patients. Tumour Biol. 2010. [PubMed]

28. Lu CC, Chang KW, Chou FC, Cheng CY, Liu CJ. Association of pretreatment thrombocytosis with disease progression and survival in oral squamous cell carcinoma. Oral Oncol. 2007 Mar;43(3):283-8.

29. Kargus S, Weber FE, Luebbers HT, Zemann W, Graetz KW, Kruse AL. Pretreatment thrombocytosis: a prognostic marker for oral squamous cell carcinoma? Oral Maxillofac Surg. 2012;16(2):197-200.

30. Ryan DH. Examination of blood cells. In: Lichtman MA, Kipps TJ, Seligsohn U, et al., eds. Williams Hematology. 8th ed. New York, NY: The McGraw-Hill Companies, Inc.; 2010:Chapter 2.

31. Perkins SL. Examination of the Blood and Bone Marrow. In: Greer JP, Foester J, Rodgers GM, et al., eds. Wintrobe's Clinical Hematology. 12th ed. Philadelphia, PA: Lippincott Williams \& Wilkins; 2009.

32. von Meyenfeldt M. Cancer-associated malnutrition: An introduction. Eur J Oncol Nurs 2005;9:S35-8.

33. Bedell SE, Bush BT. Erythrocyte sedimentation rate. From folklore to facts. American Journal of Medicine 1985;76:1001-09.

34. Paulus HE, Brahn E. Is erythrocyte sedimentation rate the preferable measure of the acute phase response in rheumatoid arthritis? Journal of Rheumatology 2004;31:838-40

35. Zenda S, Hironaka S, Boku N, Yamazaki K, Yasui $\mathrm{H}$, Fukutomi A, Yoshino T, Onozawa Y, Nishimura T. Impact of hemoglobin level on survival in definitive chemoradiotherapy for T4/M1 lymph node esophageal cancer. Dis Esophagus 2008;21(3):195-200.

\begin{tabular}{|c|c|c|c|}
\hline & & EPL & SCC \\
\hline \multicolumn{2}{|c|}{ Hypopharynx } & $2(6.7 \%)$ & $7(22.6 \%)$ \\
\hline & $\begin{array}{c}\text { Posterior } \\
\text { pharyngeal wall }\end{array}$ & 2 & 2 \\
\hline & Pyriform sinus & 0 & 3 \\
\hline & Post cricoid region & 0 & 2 \\
\hline \multicolumn{2}{|r|}{ Oral Cavity } & $21(70 \%)$ & $4(12.9 \%)$ \\
\hline & Buccal mucosa & 14 & 1 \\
\hline & $\begin{array}{l}\text { Gingivo-buccal } \\
\text { sulcus }\end{array}$ & 4 & 1 \\
\hline & \begin{tabular}{|c|} 
Alveolus \\
\end{tabular} & 1 & 2 \\
\hline \multicolumn{2}{|r|}{ Oropharynx } & $1(3.3 \%)$ & $15(48.4 \%)$ \\
\hline & RMT & 1 & 7 \\
\hline & Tonsil & 0 & 5 \\
\hline & $\begin{array}{l}\text { Lat pharyngeal } \\
\text { wall }\end{array}$ & 0 & 1 \\
\hline & Palate & 0 & 2 \\
\hline Larynx & & $6(20 \%)$ & $5(16.1 \%)$ \\
\hline & TVC & 5 & 3 \\
\hline & Supraglottis & 1 & 0 \\
\hline & Subglottis & 0 & 2 \\
\hline \multicolumn{4}{|c|}{$\begin{array}{c}\text { Table 2: Distribution of Lesion in } \\
\text { Various Head Neck Regions }\end{array}$} \\
\hline
\end{tabular}




\begin{tabular}{|c|c|c|c|c|c|}
\hline & & \multicolumn{3}{|c|}{ Mean \pm SD } & \multirow{2}{*}{$\begin{array}{c}\begin{array}{c}\text { One way } \\
\text { ANOVA }\end{array} \\
\text { P value }(<.05)\end{array}$} \\
\hline & Normal Range & $\begin{array}{c}\text { EPL } \\
N=30\end{array}$ & $\begin{array}{c}\mathrm{SCC} \\
\mathrm{N}=31\end{array}$ & $\begin{array}{c}\text { Control } \\
\mathrm{N}=\mathbf{3 0}\end{array}$ & \\
\hline TLC $\left(10^{\wedge} 3 / \mathrm{UL}\right.$ & $4 .-10$ & $7.2 \pm .8$ & $7.6 \pm 2.5$ & $7.6 \pm 2.1$ & $0.7701(\mathrm{~ns})$ \\
\hline Neutrophil (\%) & $(1.8-7)$ & $7.6 \pm 13.7$ & $4.9 \pm 2.3$ & $4.9 \pm 1.6$ & $0.3338(\mathrm{~ns})$ \\
\hline Lymphocyte (\%) & $(1-3.5)$ & $3.2 \pm 3.9$ & $1.8 \pm 1.1$ & $2.7 \pm .8$ & 0.0649 (ns) \\
\hline $\mathrm{RBC}$ & $4.6-6.0$ & $4.6 \pm .52$ & $4.5 \pm .9$ & $4.52 \pm .5$ & 0.7154 (ns) \\
\hline HCT & $40-50$ & $40.6 \pm 4.2$ & $38.3 \pm 11.1$ & $40.8 \pm 5.5$ & $0.3645(\mathrm{~ns})$ \\
\hline MCV & $80-100 \mathrm{fL}$ & $88.3 \pm 6.6$ & $83.1 \pm 18.2$ & $87.9 \pm 4.7$ & 0.1611 (ns) \\
\hline $\mathrm{MCH}$ & 27-31 pg & $27.1 \pm 2.8$ & $26.7 \pm 5.1$ & $27.7 \pm 1.3$ & $0.5182(\mathrm{~ns})$ \\
\hline MCHC & $32-36 \mathrm{~g} / \mathrm{dL}$ & $31.7 \pm 2.3 \mathrm{a}, \mathrm{a} 1$ & $29.2 \pm 3.6 \mathrm{a}, \mathrm{b}$ & $33.86 \pm 2 \mathrm{a} 1, \mathrm{~b}$ & $<.0001^{* * *}$ \\
\hline RDW SD & $39-46 \mathrm{fL}$ & $49.8 \pm 4.4 \mathrm{~d} 2$ & $48.8 \pm 4.3 \mathrm{~m}$ & $45.6 \pm 4.6 \mathrm{~m}, \mathrm{~d} 2$ & $<.0001^{* * *}$ \\
\hline RDW CV & $11.6-14.6 \%$ & $14.5 \pm .82$ & $14.7 \pm .9 \mathrm{a} 2$ & $14.1 \pm .5 \mathrm{a} 2$ & $0.0075^{* *}$ \\
\hline Platelet & $150-400$ & $227.7 \pm 66.6 b 1$ & $161.5 \pm 42.6 \mathrm{~b} 1, \mathrm{c}$ & $244.3 \pm 62.2 c$ & $<.0001^{* * *}$ \\
\hline $\mathrm{Hb} \%$ & $13.5-17.5$ & $12.4 \pm 1.8 \mathrm{~g}, \mathrm{f}$ & $11.1 \pm 1.8 \mathrm{~g}, \mathrm{c} 1$ & $13.6 \pm 1.3 \mathrm{f}, \mathrm{c} 1$ & $<.0001^{* * *}$ \\
\hline ESR (mmAEF) & $0-15$ & $30.9 \pm 14.8 \mathrm{c} 2, \mathrm{c} 3$ & $19.3 \pm 8.5 c 2, d$ & $5.1 \pm 1.9 \mathrm{c} 3, \mathrm{~d}$ & $<.0001^{* * *}$ \\
\hline
\end{tabular}

**: $\mathrm{p}<.01$ (very significant), *: p<.05(significant), ***: p<.001(extremely significant), ns: not significant. On comparing the different groups by Tukey-Kramer Multiple Comparisons test, the corresponding letters indicate the significance level between groups as follows f,m: p<.05(significant), a,a1,a2,g:P<.01 (Very significant), b,b1,c,c1,c2,c3,d2 :p<.001(extremely significant). TLC: Total leukocyte count, RBC: Red blood cell, HCT: Hematocrit, MCV: Mean corpuscular volume, MCH: Mean corpuscular hemoglobin, MCHC: Mean corpuscular hemoglobin concentration, RDW SD: Red cell distribution width Standard deviation, RDW CV: Red cell distribution width, Hb\%: Hemoglobin, ESR (mmAEF): Erythrocyte sedimentation rate.

\begin{tabular}{|c|c|c|c|c|c|}
\hline & & \multicolumn{3}{|c|}{ Mean \pm SD } & $\begin{array}{c}\text { One-way } \\
\text { ANOVA }\end{array}$ \\
\hline $\begin{array}{c}\text { BLOOD } \\
\text { BIOCHEMISTRY }\end{array}$ & $\begin{array}{c}\text { NORMAL } \\
\text { RANGE }\end{array}$ & $\begin{array}{c}\text { EPITHELIAL } \\
\text { PRECURSOR } \\
\text { LESION N=30 }\end{array}$ & $\begin{array}{c}\text { SCC } \\
\text { N=31 }\end{array}$ & $\begin{array}{c}\text { Control } \\
\text { N=30 }\end{array}$ & $\begin{array}{c}\text { P value } \\
(<.05)\end{array}$ \\
\hline Blood Urea & $15-45$ & $22.08 \pm 4.79$ & $23.75 \pm 11.38$ & $24.2 \pm 5.5$ & $0.546(\mathrm{~ns})$ \\
\hline Serum Creatinine & $.4-1.4$ & $.96 \pm .28$ & $.86 \pm .31$ & $.76 \pm .54$ & $0.144(\mathrm{~ns})$ \\
\hline Blood sugar Fasting & $<100 \mathrm{mg} / \mathrm{dL}$ & $89.21 \pm 12.28$ & $94.74 \pm 11.45$ & $92.53 \pm 16.08$ & $0.2742(\mathrm{~ns})$ \\
\hline Blood sugar Post Prandial & $<140 \mathrm{mg} / \mathrm{dL}$ & $145.9 \pm 20$ & $126.16 \pm 50.79$ & $137.6 \pm 18.25$ & $0.0745(\mathrm{~ns})$ \\
\hline \multicolumn{7}{r}{ Table 4: Blood Biochemistry Results in Different Study Groups } \\
\hline
\end{tabular}

\section{Hemoglobin \%}

\section{MCHC LEVEL}
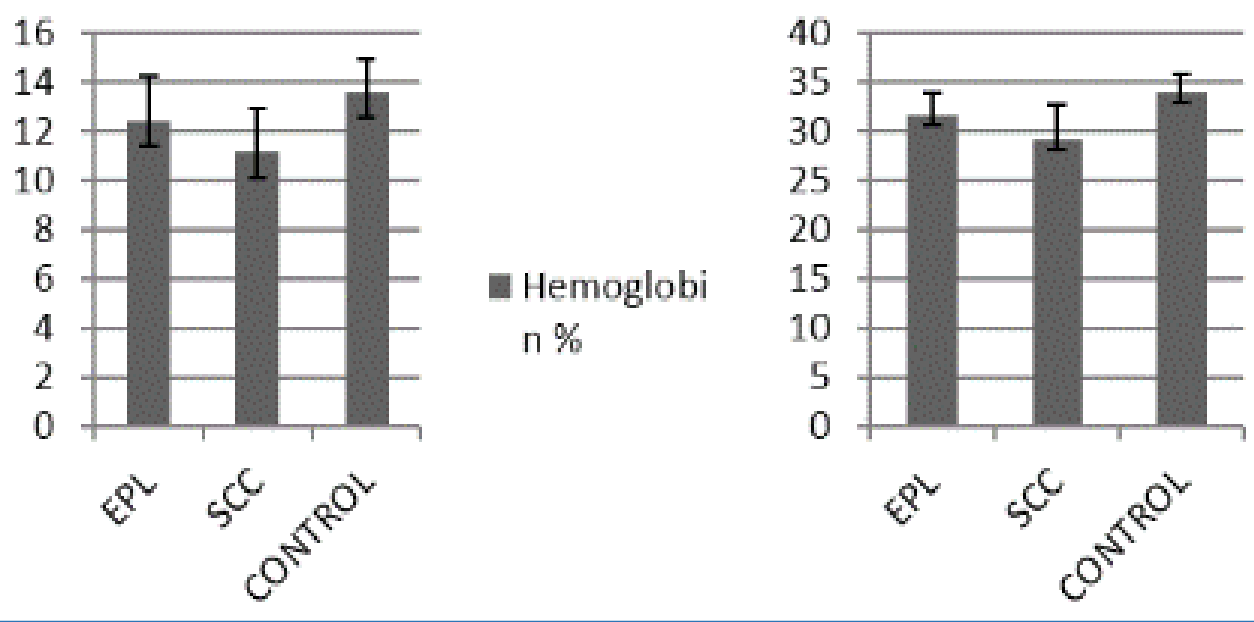

MCHC

LEVEL

$n \%$

Fig. 1: Level of Hemoglobin and MCHC Levels in Different Groups 